\title{
Pesan-Pesan Komunikasi Edukatif Dalam Mendidik Anak (Tinjauan Prespektif Komunikasi Islam)
}

\author{
Umar Abdur Rahim SM${ }^{1}$, Marlina Chandra ${ }^{2}$ \\ Dosen UIN Suska ${ }^{1}$, Dosen STAIN Mandailing Natal ${ }^{2}$ \\ Email: Umarabdur@uin-suska.ac.id ${ }^{1}$ \\ marenzhy@yahoo.co.id ${ }^{2}$
}

\begin{abstract}
Abstrak
Pembahasan ini mentela'ah tentang pesan-pesan komunikasi edukatif dalam mendidik anak dilihat dari sudut pandang prespektif komunikasi Islam yang merujuk pada Al-qur,an dan Hadist. Bagaimana sebenarnya pesan-pesan komunikasi antara orangtua dan anak yang ada dalam Al-qur,an dan hadist memiliki nilai-nilai edukatif dari orangtua ke anak yang tertuang secara tersurat dan tersirat. Pendekatan dalam kajian ini menggunakan pendekatan kajian literature kepustakaan(Library Research) dengan mempelajari dan mengumpulkan data dari berbagai literature, buku-buku serta sumber-sumber yang relevan dan mendukung kajian penelitian. Sedangkan untuk analisis data, penelitian ini menggunakan analisis deskriptif. Hasil menunjukkan bahwa dalam komunikasi Islam yang konsep dasarnya merujuk pada Al-qura,an dan hadits, terdapat banyak sekali ayat-ayat yang menjelaskan secara tersurat dan tersirat tentang komunikasi edukatif. hal ini dapat diihat dari ciri komunikasi edukatif itu sendiri didalam pesannya, yaitu adanya pesan yang berisikan penanaman nilai-nilai edukatif antar komunikator yaitu orangtua, kepada komunikan yaitu anaknya. Pesan-pesan tersebut berisikan penanaman nilai-nilai pendidikan serta penanaman keyakinan yang fundamental bagi diri manusia khusus jiwa seorang muslim yaitu nilai-nilai tauhid, aqidah dan nilai-nilai moral atau akhlak mulia yang ditanamkan orangtua kepada anaknya dalam segala hal kehidupan termasuk dalam hal komunikasi.
\end{abstract}

\section{Kata Kunci: Pesan; Komunikasi Edukatif; Komunikasi Islam}

\section{PENDAHULUAN}

Komunikasi merupakan sesuatu yang sangat urgen dalam setiap lini kehidupan manusia. Seperti halnya sebuah pohon, komunikasi di ibaratkan bagai tanah atau pun air yang harus ada demi keberlangsungan hidup pohon tersebut. Melalui komunikasi manusia dapat saling berhubungan satu sama lain baik dalam kehidupan sehari-hari, dirumah, dikantor, dipasar, dalam kehidupan bermasyarakat, dan lain sebagainya. Tidak ada manusia yang tidak terlibat dalam komunikasi ${ }^{1}$.

Harus diakui bahwa manusia tidak bisa hidup tanpa adanya komunikasi. Dengan berkomunikasi, manusia bisa melakukan hal-hal penting dalam hidupnya. Sebaliknya tanpa adanya komunikasi di dalam kehidupannya, maka akan mengakibatkan ketidakteraturan bagi kehidupan manusia dalam melakukan kegiatan

\footnotetext{
${ }^{1}$. Arni Muhammad, Komunikasi Organisasi,(Jakarta: PT.Bumi Aksara, 2014). hal.1
} 
sehari-hari baik itu kegiatan di rumah, dalam suatu organisasi atau perusahaan maupun dalam lingkungan masyarakat dimanapun manusia itu berada. Begitu urgennya komunikasi sehingga ia sudah merupakan bagian yang harus ada dalam kehidupan manusia. Komunikasi menjadi bagian inti dalam kehidupan manusia baik secara individu, maupun secara kolektif ${ }^{2}$ dalam kehidupan sosial maupun kehidupan bermasyarakat yang lebih luas yaitu dalam kehidupan berbangsa dan bernegara.

Pembahasan tentang komunikasi adalah sebuah pembahasan yang menarik dan sangat luas. Jika dipandang dari segi keilmuan, hampir semua disiplin bidang keilmuan selalu terkait dengan komunikasi. Begitu juga halnya dalam aplikasinya, hampir semua dimensi kehidupan juga tidak dapat dilepaskan dari sentuhan komunikasi didalamnya. Begitu melekatnya hubungan komunikasi dan manusia, sehingga komunikasi dan manusia dalam segala aspek kehidupannya sudah menjadi bagian kekal seperti halnya bernapas dalam kehidupan manusia yang tidak dapat dipisahkan satu dengan yang lainnya. Sepanjang manusia ingin hidup maka ia perlu berkomunikasi ${ }^{3}$.

Komunikasi ini pula yang menjadi bukti bahwa manusia adalah makhluk sosial yang tidak dapat hidup secara sendiri-sendiri. Manusia merupakan makhluk yang saling membutuhkan antara satu dengan yang lainnya. Melalui komunikasi manusia berinteraksi antara satu individu dengan individu lainnya, antara pimpinan dengan bawahannya, antara guru dengan muridnya begitu juga antara orangtua dengan anaknya. Jika dikaji, aktifitas komunikasi sesungguhnya telah dilakukan manusia sejak dari awal keberadaan manusia dimuka bumi, yaitu komunikasi antara orangtua dan anaknya. Komunikasi antara orangtua dan anak adalah merupakan salah satu bentuk aplikasi komunikasi yang paling pertama sekali dilakukan manusia kepada sesamanya setelah ia dilahirkan. Bahkan jika kita coba menelisik lebih dalam, aktifitas komunikasi yang dilakukan oleh manusia sesungguhnya telah jauh dilakukan manusia sebelum ia dilahirkan kemuka bumi yaitu komunikasi yang dilakukan antara seorang anak yang masih berupa janin dengan ibunya sejak ia berada didalam kandungan.

Hadirnya komunikasi dalam diri manusia adalah sebuah teknologi atau perangkat bawaan dasar "default setting" yang diberikan Tuhan kepada manusia. Perangkat dasar ini diberikan Tuhan agar manusia bisa tumbuh dan berkembang serta menjaga eksistensinya dan menjadi control yang dapat memberikan kestabilan bagi diri manusia sendiri. Dengan adanya komunikasi, manusia dapat mengontrol dan menjaga kestabilan dirinya dan kehidupannya secara fisik. Begitu juga halnya dalam dimensi jiwa, dengan adanya komunikasi manusia dapat mengontrol dan menjaga kestabilan dirinya dan kehidupannya secara kejiwaan. Begitu juga halnya dengan komunikasi antara orangtua dan anak. Komunikasi yang dilakukan orangtua dan anak atau sebaliknya merupakan sebuah hasrat naluriah dan alamiah yang ada dalam

\footnotetext{
2 .Ngainun Naim. Dasar-dasar Komunikasi Pendidikan. (Yogyakarta: Ar- Ruzz Media. 2011).hal.27

${ }^{3}$. Hafied Cangara, Pengantar Ilmu Komunikasi (Jakarta:RajaGrafindo Persada,2005). hal.1
} 
diri manusia untuk mengontrol diri dan lingkungan sekitarnya. Komunikasi dilakukan manusia untuk beradaptasi, serta sebagai upaya mentranformasikan nilainilai sosial atau warisan sosial yang ada dalam diri manusia itu sendiri. Terlebih anak adalah penerus nilai-nilai dan warisan sosial manusia yang harus dirawat dan dijaga tumbuh kembangnya. Baik tumbuh kembang secara fisik maupun tumbuh kembangnya secara kejiwaan.

Dalam ajaran Islam anak adalah sebuah anugerah yang telah Allah Swt berikan kepada orangtua. Anak terlahir dalam keadaan putih bersih tanpa noda. Anak terlahir dalam keadaan fitrah orangtuanya-lah yang kemudian memberikannya warna berupa penenaman nilai-nilai kepada dirinya yang bisa jadi buruk jika dituntun dan dibimbing oleh petunjuk yang salah, dan bisa jadi baik jika penanaman nilai-nilai tersebut di tuntun dengan nilai-nilai dan petunjuk yang benar. Untuk mewujudkan penanaman nilai-nilai tersebutlah maka perlu adanya sebuah komunikasi efektif yang harus ada dalam setiap aktifitas komunikasi yang dilakukan dan untuk melakukan hal tersebut, maka para guru atau para orangtua perlu mengetahui konsep-konsep yang tepat dalam mendidik anak yang berisikan pesan-pesan positif yang bersifat mendidik dan komunikatif atau disebut juga dengan komunikasi edukatif yang sesuai dengan arahan dan tuntunan agama sebagai jalan petunjuk bagi manusia agar selamat dan bahagia dunia akhirat.

Komunikasi edukatif adalah merupakan komunikasi yang dilakukan oleh dua orang atau lebih didalamnya terdapat nilai-nilai edukatif yang bersifat mendidik ${ }^{4}$ atau proses komunikasi yang dilakukan demi terwujudnya tujuan yang hendak dicapai yaitu dalam hal yag bersifat mendidik. Pendidikan merupakan sebuah proses untuk mengangkat harkat, martabat dan kesiapan manusia dalam menghadapi masa depannya yang penuh dengan tantangan, serta mengamalkan nilai-nilai yang terkandung dalamnya ${ }^{5}$. Di lihat dari pesan yang ada didalamnya, maka pesan yang disampaikan dalam komunikasi edukatif adalah pesan-pesan yang berisi ajaran atau penanaman nilai-nilai antara satu manusia kepada manusia lainnya,baik komunikasi yang dilakukan antara guru dengan muridnya maupun komunikasi antara orangtua dan anaknya.

Dalam ajaran Islam, banyak sekali pesan-pesan yang berisikan tentang metode, prinsip dan konsep-konsep dasar yang memberikan penjelasan dan tuntunan dalam melakukan komunikasi yang baik dan benar. Terlebih dalam komunikasi yang dilakukan untuk mengajak orang kearahan yang lebih baik dan komunikasi yang berisikan gambaran bagaimana komunikasi yang dilakukan oleh orangtua dalam menanamkan nilai-nilai penting berupa nilai-nilai tauhid maupun nilai-nilai kehidupan sosial kepada anaknya.

\footnotetext{
${ }^{4}$. Mukhlison Effendi. Komunikasi Orang Tua Dengan Anak "Keharusan Yang Sering Terabaikan".(Ponorogo: STAIN Ponorogo Press, 2012). hal. 25

5 . Abdul Hadi, Konsep Pendidikan Al-Farabi dan Ibnu Sina.( Jurnal Ilmiah Sintesa, Vol. 9. No. 2, Januari 2010) hal.14.
} 
Sehingga mengkaji dan membahas tentang komunikasi dengan menela'ah konsep dalam prespektif komunikasi Islam yang bersumber pada Al-quran dan AsSunnah adalah sebuah proses penggalian ilmu yang tidak ada habisnya dan akan terus membuka khazanah dan penemuan konsep-konsep keilmuan baru yang terus berkembang. Oleh karena ini pembahasan mengenai bagaimana komunikasi edukatif dalam mendidik anak dalam prespketif komunikasi Islam yang merujuk pada Alquran menjadi sesuatu yang sangat menarik untuk dikaji.

\section{KAJIAN TEORITIS}

\section{Definisi Komunikasi}

Secara etimologi komunikasi berasal dari bahasa Latin yaitu dari kata communicatio yang bersumber dari kata communisi yang berarti sama. Dalam hal dasar ini, arti sama dimaknai sebagai kesamaan makna ${ }^{6}$ yaitu sesuatu yang diberikan makna yang sama antara yang satu dengan yang lainnya. Kata tersebut kemudian berkembang dalam bahasa Inggris menjadi Communication yang artinya proses pertukaran informasi, konsep, gagasan, ide, perasaan dan lain-lain. Secara sederhana dapat dikemukakan pengertian komunikasi ialah proses pengiriman pesan atau simbol-simbol yang mengandung arti yang sama dari seorang sumber atau komunikator kepada seorang komunikan dengan tujuan tertentu. ${ }^{7}$

Dalam sudut pandang kesamaan pertukaran makna ini, komunikasi dapat didefinisikan sebagai sebuah proses penyampaian makna dalam bentuk gagasan atau informasi dari seseorang kepada orang lain melalui media tertentu. Kesamaan makna merupakan hal terpenting sebagai inti dari proses komunikasi tersebut. Seorang komunikan diharapkan mampu memberikan respon atau feedback dari pesan atau informasi yang disampaikan ketika proses komunikasi berlangsung. Respon atau feedback yang diberikan tersebut yaitu berkaitan dengan arti atau makna yang disampaikan dalam pesan.

Harold D.Lasswell mendefinisikan komunikasi dengan definisi yang lain namun lebih rinci. Lasswel mendefinisikan bahwa komunikasi adalah "who, says what, in which channel, to whom, with what effect". Dalam terminologi ini Lasswel mendefinisikan komunikasi melalui lima unsur yang bahwa setidaknya harus ada dalam komunikasi yaitu "siapa, mengatakan apa, dengan menggunakan media apa, kepada siapa, dan memiliki dampak apa”. Carl I. Hovland dalam definisnya juga mendefinisikan komunikasi seirama dengan definisi komunikasi di atas. Hovland berpendapat bahwa komunikasi adalah "The process by which an individual (the communicator transmits stimuli (usualy verbal symbols) to modify

\footnotetext{
${ }^{6}$. Onong Uchjana E. Ilmu komunikasi, teori dan praktik( Bandung, PT, Remaja Rosdakarya 2011) hal. 9

7. Suranto AW, Komunikasi Sosial Budaya. ( Yogyakarta: Graha Ilmu, 2010) hal. 2
} 
the behavior of other individulas cummunicatees". Hovland mendefinisikan bahwa komunikasi adalah sebuah proses dimana seseorang komunikator memberikan stimulus(yang biasanya berupa pesan verbal) kepada orang lain, untuk mengubah sikap atau perilakunya.

Di sini, dapat dilihat bahwa Hovland tegas-tegas mengetengahkan atau mengatakan kalimat "to modify the behavior of other individulas" yang dalam definisi ini menjelaskan bahwa, komunikasi bukanlah hanya persoalan mengerti atau tidak mengerti saja, akan tetapi lebih luas lagi dari itu. Menurutnya komunikasi ialah proses dimana seseorang komunikator menyampaikan perangsang-perangsang yang biasanya dikirim dalam bentuk lambang-lambang (biasanya symbol verbal) untuk merubah tingkah laku orang lain atau komunikan. Dalam arti yang lebih tegas, hovland menggaris bawahi bahwa komunikasi bukanlah hanya suatu proses dalam menyampaikan pesan-pesan atau informasi kepada orang lain agar mereka mengerti saja, akan tetapi lebih dari itu yaitu agar berubah tingkah lakunya. ${ }^{8}$

Berdasarkan beberapa definisi mengenai komunikasi tersebut, dapat disimpulkan bahwa komunikasi merupakan proses pengiriman pesan oleh komunikator yang kemudian diterima dan diinterpretasikan oleh komunikan, dengan tujuan untuk mencapai kesamaan makna dan pandangan serta adanya perubahan perilaku dan sikap dari proses komunikasi yang dilakukan. Sehingga untuk mendapatkan hasil yang maksimal yaitu adanya perubahan sikap, maka sebagai suatu proses penyampaian informasi, individu yang terlibat dalam kegiatan komunikasi khususnya para komunikator perlulah merancang dan menyajikan informasi yang benar dan tepat sesuai setting komunikasi, dan informasi tersebut. Komunikasi disajikan dengan menggunakan bahasa yang sesuai dengan tujuan, situasi komunikasi dan tingkat nalar penerimaan komunikan. Sehingga jika itu dilakukan, maka apa yang menjadi tujuan dan fungsi komunikasi dapat tercapai yaitu untuk menginformasikan (to inform), untuk menghibur (to entertain), untuk mempengaruhi (to influnce)dan juga Untuk mendidik (to educate).

\section{Komunikasi Edukatif}

Secara definisi, komunikasi edukatif dapat diartikan sebagai komunikasi yang dilakukan oleh dua orang atau lebih yang memiliki nilai edukatif atau bersifat mendidik. Menurut Syaiful Bahri Djamarah, definisi komunikasi edukatif atau interaksi edukatif adalah hubungan dua arah antara pendidik dan anak didik

${ }^{8}$. Carl I. Hovland.Social Communication, Dalam Bernard Berlson \& Morris Janowitz (ed), Reader in Public Opinion and Communication.(New York: The Free Press of Glencoe,1953).hal.182 
dengan sejumlah norma sebagai mediumnya untuk mencapai tujuan pendidikan ${ }^{9}$. Sedangkan menurut Ngainun Naim, komunikasi pendidikan dapat diartikan sebagai komunikasi yang terjadi dalam suasana pendidikan. Dengan demikian, komunikasi pendidikan adalah proses perjalanan pesan atau informasi yang merambah bidang atau peristiwa-peristiwa pendidikan ${ }^{10}$. Sehingga kegiatan komunikasi dalam dunia pendidikan dikendalikan dan dikondisikan untuk mencapai tujuan-tujuan pendidikan. Pendidikan merupakan sebuah proses untuk mengangkat harkat, martabat dan kesiapan manusia dalam menghadapi masa depannya yang penuh dengan tantangan, serta mengamalkan nilai-nilai yang terkandung dalam pendidikan ${ }^{11}$.

Proses pendidikan pada dasarnya adalah merupakan suatu proses komunikasi, yaitu proses yang didalamnya terdapat penyampaian pesan dari komunikator kepada komunikan. Pesan yang disampaikan dalam komunikasi edukatif yaitu berupa isi atau ajaran atau nilai-nilai yang dituangkan dalam proses pembelajaran antara guru dan peserta didik. Pendidikan sering dimaknai sebagai suatu bentuk transmisi nilai atau budaya dari pendidik kepada peserta didik atau dari orangtua kepada anak-anaknya. Pendidikan sebagai suatu upaya transmisi nilai dari seseorang kepada orang lain. Proses transmisi nilai tersebut terjadi melalui komunikasi antara pendidik (guru) dan peserta didik atau antara orangtua dan anak-anaknya. Komunikasi yang terjadi dalam rangka transmisi nilai ini sesungguhnya merupakan suatu komunikasi edukatif. Tidak semua bentuk komunikasi merupakan komunikasi edukatif atau komunikasi pendidikan. Aspek yang paling substansial dalam komunikasi pendidikan yaitu terjadinya transmisi nilai yang berisikan pesan-pesan dengan nilai-nilai yang bersifat mendidik dan adanya perubahan persepsi dan perubahan sikap dari proses komunikasi yang dilakukan.

Onong Uchjana Effendy menyebutkan bahwa tujuan dari kegiatan komunikasi adalah adanya perubahan sikap (attitude change), perubahan pendapat (opinion change), perubahan perilaku (behavior change) dan perubahan sosial (social change $)^{12}$ yang terjadi pada diri komunikan setelah atau ketika komunikasi itu berlangsung. Perubahan sikap, yaitu adanya perubahan dari sikap komunikan sesuai dengan apa yang diinginkan komunikator setelah dilakukan suatu proses komunikasi. perubahan pendapat, yaitu adanya perubahan pendapat dalam diri seorang komunikan dalam suatu komunikasi yang tengah dan sudah berlangsung, perubahan perilaku, yaitu terjadinya perubahan perilaku setelah komunikan menerima pesan-pesan yang disampaikan oleh komunikator dan hal tersebut dapat

\footnotetext{
9 . Syaiful Bahri Djamarah. Guru dan Anak Didik dalam Interaksi Edukatif.(Jakarta: PT Rineka Cipta, 2005). hal.11

10. Ngainun Naim. Dasar-dasar Komunikasi Pendidikan. (Yogyakarta: Ar-Ruzz Media,2011) hal.27

11 . Abdul Hadi, Konsep Pendidikan Al-Farabi dan Ibnu Sina, Jurnal Ilmiah Sintesa,hal. 14.

12 . Effendy, Onong Uchjana. Komunikasi teori dan praktek. (Bandung : PT Remaja

Rosdakarya,2009). hal.8
} 
terjadi bilamana dalam suatu proses komunikasi apa yang dikemukakan komunikator sesuai dengan yang disampaikannya dan sangat tergantung dari kredibiltas komunikator itu sendiri.

Terakhir perubahan sosial, yaitu terjadinya perubahan yang ada dalam tatanan sosial masyarakat itu sendiri sesuai dengan lingkungan ketika berlangsungnya komunikasi ${ }^{13}$. Dimana keempat aspek perubahan tersebut dapat terwujud bilamana komunikasi yang dilakukan dapat berjalan dengan baik dan efektif. Efektif tidaknya komunikasi yang dilakukan antara komunikator dan komunikan tersebut dapat dilihat dari sejauh mana tujuan dan fungsi komunikasi tersebut dapat dicapai. Kerberhasilan awal dalam suatu proses komunikasi tersebut dapat dilihat jika komunikan bersedia memberi perhatian penuh ketika proses komunikasi itu berlangsung.

Keberhasilan komunikasi juga tercapai apabila komunikan dapat memahami pesan yang disampaikan. Selanjutnya, keberhasilan komunikasi akan tercapai apabila terdapat kesediaan menerima pesan oleh komunikan. Dengan demikian, apabila dalam proses komunikasi terdapat ketiga hal tersebut, maka dapatlah dikatakan bahwa proses komunikasi tersebut berjalan dengan baik dan efektif serta berhasil.

\section{Konsep Dasar Komunikasi Islam}

Secara etimologi, jika coba ditarik dari bahasa Arab, kata komunikasi dikenal atau dapat dkaitkan dengan istilah Al-Ittisal yang berasal dari akar kata wasola yang berarti "sampaikan" ". Kata ini dapat dilihat dalam Al-Qur"an padasurat Al-Qashass ayat 51 yang berbunyi:

"Dan sesungguhnya Kami telah sampaikan berturut-turut perkataan ini(Alquran) kepada mereka agar mereka mendapat pelajaran”.

Selain kata Al-Ittisal, dalam Al-quran juga terdapat kata-kata lain yang dapat dikaitkan dan semakna dengan kata atau merujuk pada aktivitas komunikasi yang di antaranya adalah kata "balighu" yang mempunyai arti sama dengan Al-Ittisal yang artinya"sampaikan" yang dapat dilihat dalam surat Al-Maidah ayat 67, kata 'Qull" yang artinya katakanlah yang diantaranya dapat dilihat dalam surat AlIkhlas, Al-Falaq dan An-Nass, Kata "Yad'u atau Ud'u" yang artinya menyeru, memanggil atau mengajak yang dapat dilihat dalam surat An-Nahl ayat 125, dan Al-Imron ayat 104, dan lain sebagainya. Sedangkan secara terminologi, ada beberapa istilah yang dapat mendifinisikan komunikasi Islam. Hussain mendefinisikan komunikasi Islam sebagai suatu proses menyampaikan pesan atau

13. Onong Uchjana Effendy. Ilmu, teori dan filsafat komunikasi. (Bandung : Citra Aditya Bakti, 2003).hal. 55

14. Syukur Kholil, Komunikasi Islam (Bandung: Citapustaka Media, 2007) hal.1 
informasi dari komunikator kepada komunikan dengan menggunakan prinsip dan kaedah komunikasi yang terdapat pada Al-quran dan Hadist.

Sedangkan Mahyuddin mendifinisikan komunikasi Islam sebagai sebuah proses penyampaian atau pengoperan hakikat kebenaran agama Islam kepada khalayak yang dilaksanakan secara terus-menerus dengan berpedoman pada Alquran dan Hadist, baik secara langsung atau pun tidak, baik melalui perantraan media umum atau pun khusus, yang bertujuan untuk membentuk pandangan umum yang benar berdasarkan hakikat kebenaran agama dan memberi kesan kepada kehidupan seseorang dalam aspek aqidah, ibadah maupun muamalah ${ }^{15}$. Secara sederhana, komunikasi menurut Islam adalah komunikasi yang sesuai dengan Al-Quran dan Sunah. Komunikasi Islam adalah proses penyampaian pesan-pesan keislaman dengan menggunakan pesan-pesan dan prinsip-prinsip komunikasi yang ada dalam ajaran dan nilai-nilai Islam. Dengan pengertian demikian, maka komunikasi Islam menekankan pada unsur pesan (message), yakni risalah atau nilai-nilai ajaran Islam, cara penyampaian yang dalam hal ini tentang metode dan strategi penyampaian, penggunaan bahasa, dan lain sebagainya.

Adapun isi dari pesan-pesan keislaman yang disampaikan dalam komunikasi Islam meliputi seluruh aspke ajaran Islam, diantaranya meliputi akidah atau yang terkait dengan nilai-nilai keimanan, syariah atau yang terkait dengan ketentuan aturan hukum, akhlak yang berkaitan dengan tata nilai, etika dan norma dan semua pesan-pesan baik yang bersumber dan sesuai dengan Al-quran dan Hadist baik secara implisit maupun secara eksplisit. Sehingga dalam perspektif ini, komunikasi Islam dapat di definisikan sebagai keseluruhan proses penyampaian atau keseluruhan aktivitas tukar menukar informasiyang berisikan pesan-pesan ajaran Islam, dan menggunakan prinsip-prinsipserta kaedah-kaedah komunikasi yang sesuai dengan pesan-pesan ajaran Islamyang bersumber pada Al-quran dan Hadist.

\section{METODOLOGI}

Jenis penelitian ini berbentuk penelitian kepustakaan (Library Research). Penelitian kepustakaan ialah penelitian yang dilaksanakan dengan menggunakan dan mengumpulkan literatur (kepustakaan), baik berupa buku, catatan, maupun laporan hasil penelitian terdahulu ${ }^{16}$.Sedangkan untuk analisis data, penelitian ini menggunakan analisis deskriptif yaitu suatu metode dengan jalan mengumpulkan data, menyusun atau mengklasifikasi, menganalisis dan menginterpretasikannya ${ }^{17}$.

\footnotetext{
15 . Ibid, hal.2

${ }^{16}$.IqbaI Hasan, Analisis Data Penelitian Dengan Statistik,(JakartaBumi Aksara, 2008), hal. 5.

${ }^{17}$.Muhammad Natsir, Metode Penelitian, ( Jakarta : Ghalia Indonesia, 1999) hal. 64
} 


\section{PEMBAHASAN}

\section{Pesan Komunikasi Dalam Mendidik Anak Prespektif Komunikasi Islam}

Komunikasi adalah sebuah aktifitas fundamental yang paling mendasar yang tidak bisa dipisahkan dan sangat penting di dalam kehidupan manusia, Komunikasi menjadi penting karena ia merupakan bagian dari diri manusia baik secara individu maupun secara sosial. Ia mengatur semua hubungan yang ada dalam diri dan dalam kehidupan manusia. Komunikasi adalah merupakan kebutuhan utama kita sebagai manusia yang sehat secara rohaniah dan jasmaniah adalah kebutuhan akan adanya hubungan sosial dengan yang lainnya, di mana ini dapat dicapai dengan melakukan dan membina hubungan yang baik dengan orang lain dan untuk mencapai itu hanya bisa didapat dengan melakukan komunikasi yang baik dan tepat kepada orang lain.

Harold D. Lasswell salah seorang peletak dasar ilmu komunikasi lewat ilmu politik Sebagaimana yang dikutip Cangara dalam bukunya Pengantar ilmu komunikasi menyebutkan bahwa, ada tiga fungsi yang sangat mendasar yang menjadi penyebab mengapa manusia perlu berkomunikasi. Adapun tiga fungsi tersebut adalah:

Pertama, hasrat manusia untuk mengontrol lingkungannya. Melalui komunikasi manusia dapat mengetahui peluang-peluang yang ada untuk dimanfaatkan, dipelihara, dan menghindar pada hal-hal yang mengancam alam sekitarnya. Melalui komunikasi manusia dapat mengetahui suatu kejadian atau peristiwa. Bahkan, melalui komunikasi pula manusia dapat mengembangkan pengetahuannya, yakni belajar dari pengalamannya maupun melaui informasi yang mereka terima dari lingkungan sekitarnya.

Kedua, adalah upaya manusia untuk dapat beradaptasi dengan lingkungannya. Proses kelanjutan suatu masyarakat, sesungguhnya tergantung bagaimana masyarakat tersebut bisa beradaptasi denan lingkungannya. Penyesuaian disini bukan saja terletak pada kemampuan manusia memberikan tanggapan terhadap gejalagejala alam seperti banjir, gempa bumi dan musim yang mempengaruhi perilaku manusia, tetapi juga lingkungan masyarakat tempat manusia hidup dalam tantangan. Dalam lingkungan seperti ini, diperlukan penyesuaian agar manusia dapat hidup dalam suasana yang harmonis.

Ketiga, adalah upaya untuk melakukan transformasi warisan sosial. ${ }^{18}$ Suatu masyarakat yang ingin mempertahankan keberadaannya, maka anggota masyarakatnya dituntut untuk dapat melakukan pertukaran nilai, perilaku dan peranan. Misalnya bagaimana orangtua mengajarkan tata krama bermasyarakat yang baik kepada anak-anaknya, bagaimana sekolah difungsikan untuk mendidik warga negaranya, bagaimana media massa menyalurkan hati nurani khalayaknya, dan bagaimana pemerintah dengan kebijaksanaan yang dibuatnya untuk mengayomi kepentingan rakyat atau anggota masyarakatnya.

${ }^{18}$ Hafied Cangara, Pengantar Ilmu Komunikasi (Jakarta: RajaGrafindo Persada, 2008) hal.2 
Ketiga fungsi ini menjadi patokan dasar bagi dan dalam kehidupan setiap individu dalam berhubungan dengan sesama anggota masyarakat lainnya. Sehingga, komunikasi jelas tidak dapat dipisahkan dengan kehidupan umat manusia baik dalam kehidupan individu maupun dalam kehidupan sosial di dalam masyarakat yang lebih luas lagi. Jika dilihat dari urgensinya dalam prespektif komunikasi Islam yang bersumber pada Al-qur,an dan hadist, maka komunikasi merupakan hal yang sangat urgen dalam diri manusia terlebih bagi seorang anak. Lewat komunikasi, anak mengenal diri dan lingkungannya. Hal ini dapat dilihat gambarkan dalam Al-Hujarat ayat 10 yang artinya :

"orang-orang beriman itu Sesungguhnya bersaudara. sebab itu damaikanlah (perbaikilah hubungan) antara kedua saudaramu itu dan takutlah terhadap Allah, supaya kamu mendapat rahmat".

Dari ayat ini dapat dilihat bahwa bagaimana komunikasi memduduki posisi yang sangat urgen bagi diri manusia. Perilaku komunikasi yang dipelajari manusia pertama sekali dalam hidupnya, sudahlah di mulai sejak manusia itu bayi, yaitu berkomunikasinya seorang bayi dengan orangtuanya. Bayi menangis adalah sebuah bentuk komunikasi awal yang dilakukannya dengan mengirimkan sinyal-sinyal atau respon yang ia mampu yaitu berupa tangisan atas upaya bayi untuk memenuhi kebutuhan hidupnya. Hingga akhirnya dengan tangisan tersebut, orangtuanya merespon dengan belajar memahami komunikasi sang bayi dan kemudian menentukan upaya apa yang akan diberi dan ia lakukan kepada si bayi sesuai dengan respon komunikasi yang bayi berikan serta yang si ibu pahami.

Dengan kata lain, disini anak dan ibu saling melakukan komunikasi. Anak membalas komunikasi orangtuanya, begitu juga si ibu beradaptasi terhadap anaknya sendiri berdasarkan respon yang diberikan si anak berulang kali kepadanya, sehingga akhirnya sang ibu dapat berkomunikasi dengan si anak setelah mampu mengerti bentuk-bentuk tingkah laku, suara dan tangis anaknya, apakah sang anak marah, sakit, lapar, kesepian, atau sekedar bosan dan lain sebagainya. Pesan-pesan ini terkadang sulit dipahami oleh orang lain kecuali ibu sendirinya. Komunikasi ini kemudian berlanjut ketika ia bertumbuh dan berkembang dan begitu seterusnya. Sehingga dapat dilihat bahwa, aktifitas komunikasi yang paling awal dilakukan manusia adalah komunikasi yang dilakukan oleh orangtua dan anak dalam sebuah keluarga. Pola komunikasi yang bersumber dari keluarga ini pula nantinya yang kemudian akan ia bawa dalam komunikasi yang lebih luas lago dalam lingkungan masyarakat dan lingkungan sekitarnya.

Berbicara dan membahas tentang pendidikan dan perkembangan anak, adalah suatu bahasan yang selalu saja menarik. Setiap kali membicarakan tentang perkembangan anak, maka pembahasan ini tidak pernah lepas dari peran orangtua dalam sebuah keluarga. Orangtua adalah lingkungan pertama yang dikenal anak dan sangat berperan penting bagi perkembangan dan tumbuh kembang anak. Melalui orangtua anak belajar menanggapi mengenal dirinya, orang lain, dan sekaligus 
belajar berkomunikasi dengan orang lain dan lingkungan sekitarnya. Komunikasi antara anak dan orangtua merupakan dasar bagaimana orangtua dan anak membentuk hubungannya. Selain itu komunikasi orangtua dan anak juga adalah proses tranformasi warisan sosial budaya yang merupakan hal awal dimana anak mendapatkan penanaman nilai-nilai dasar yang ia dapatkan dari orangtuanya.

Salah satu hal yang dapat menunjang hal ini adalah dengan adanya komunikasi dengan anak. Komunikasi yang buruk antar orangtua dan anak tentu dapat membuat hubungan orangtua dan anak bertambah buruk, sebaliknya komunikasi yang baik dan tepat tentu akan dapat membuat hubungan orangtua dan anak serta penanaman nilai-nilai serta perubahan perilaku yang diharapkan orangtua dapat berjalan dengan baik dan sesuai dengan apa yang diharapkan. Namun, pada realitanya banyak orangtua yang tidak menyadari hal ini. Komunikasi orangtua dengan anak masih dianggap hal yang sepele dan jarang diperdulikan. Hak-hak anak yang seharusnya dia dapatkan sesuai dengan kebutuhan dan perkembangan di usianya, sering diabaikan oleh para orangtua. Padahal hak dan hal komunikasi dengan anak adalah suatu hal yang sederhana, mudah dilakukan, dan memiliki manfaat yang besar terhadap tumbuh kembang anak, baik secara fisik, maupun tumbuh kembangnya anak secara kejiwaan.

Abraham Maslow mengemukakan ada lima kebutuhan yang menjadi kebutuhan dasar manusia, yaitu kebutuhan fisiologis, keamanan, kebutuhan sosial, penghargaan diri, dan kebutuhan aktualisasi diri. ${ }^{19}$ Dan semua ini akan anak dapatkan bila sejak awal ia mendapatkan komunikasi dengan penanaman nilai-nilai dan pesan-pesan komunikasi yang baik dan edukatif dari orangtuanya. Pesan ialah apa yang dikomunikasikan oleh sumber atau komunikator kepada penerima berupa informasi dan lain sebagainya. Pesan merupakan seperangkat simbol atau lambang verbal dan non verbal yang mewakili perasaan, nilai, gagasan, maksud dari sumber ${ }^{20}$.Pesan merupakan bagian adalah bagian dari unsur yang harus ada dalam komunikasi. Tanpa pesan, maka bisa dipastikan, komunikasi tidak akan pernah terjadi. Dalam istilah komunikasi pesan disebut juga dengan message, content atau informasi $^{21}$. Isi pesan, bisa berupa banyak hal, termasuk juga didalamnya pesanpesan komunikasi yang dilakukan dalam rangka mendidik.

Pendidikan merupakan sebagian dari fenomena kehidupan sosial manusia. Menurut K.J. Veeger pada hakekatnya kehidupan sosial itu terdiri dari jumlah aksi dan reaksi yang tidak terbilang banyaknya, baik antara perorangan maupun antara kelompok. Pihak-pihak yang terlibat menyesuaikan diri dengan salah satu pola yang kolektif. Kesatuan yang berasal dari penyesuaian diri itu disebut kelompok atau masyarakat. Oleh karenannya pendidikan merupakan bagian dari interaksi sosial

\footnotetext{
19. Riswandi, Ilmu Komunikasi (Jakarta: Graha Ilmu Cetakan Pertama, 2009). hal. 16.

20. Wahyu Ilahi. Komunikasi Dakwah.hal 97

21 . Hafied Cangara.Pengantar Ilmu Komunkasi, hal.24
} 
yang telah ada bersamaan dengan kehidupan manusia ${ }^{22}$. Pendidikan merupakan sebuah proses untuk mengangkat harkat, martabat dan kesiapan manusia dalam menghadapi masa depannya yang penuh dengan tantangan, serta mengamalkan nilainilai yang terkandung dalam pendidikan ${ }^{23}$. Proses pendidikan pada dasarnya adalah merupakan suatu proses komunikasi, yaitu proses yang didalamnya terlibat dua hal yaitu terdapat tranformasi nilai-nilai atau penyampain pesan yang dilakukan oleh seorang komunikator kepada penerima pesan yaitu komunikan.

Komunikasi dalam tujuan dan fungsinya mempunyai benang merah yang sama dengan apa yang ada dalam pendidikan. Bila dalam pendidikan terdapat transformasi nilai-nilai, maka dalam tujuan dan fungsi komunikasi pun terdapat hal yang sama. Onong Uchjana Effendy menyebutkan bahwa tujuan dari kegiatan komunikasi adalah adanya perubahan sikap (attitude change), perubahan pendapat (opinion change), perubahan perilaku (behavior change) dan perubahan sosial (social change). ${ }^{24}$ Begitu juga halnya dengan fungsi komunikasi, bila dalam pendidikan mempunyai fungsi untuk mentranformasi informasi dan nilai-nilai yang bersifat mendidik, maka dalam komunikasi pun terdapat fungsi yang sama yaitu untuk menginformasikan(to inform), untuk menghibur (to entertain), untuk mempengaruhi (to influnce) dan juga Untuk mendidik (to educate).

Dalam prespektif komunikasi Islam yang merujuk pada Al-qur,an dan hadist, pesan-pesan dasar komunikasi edukatif mempunyai ciri yaitu memiliki tujuan dan fungsi penanaman nilai-nilai edukatif atau pesan-pesan yang mendidik. Pesan-pesan komunikasi edukatif tersebut dapat dilihat dalam banyak ayat yang ada dalam Alqur,an dan hadist. Pesan-pesan tersebut berisi beberapa penanaman nilai-nilai yang sangat penting dan besar pengaruhnya dalam kehidupan anak. Pesan dalam prespektif komunikasi Islam, adalah pesan-pesan yang bersumber dari ajaran Islam. Secara garis besar, pesan-pesan tersebut berkaitan dengan penanaman nilai-nilai yang erat kaitannya dengan aqidah atau masalah keimanan, syariah atau pembahasan yang berhubungan dengan sendi-sendi keislaman, akhlaqul karimah atau pembahasan tentang etika atau nilai-nilai yang mengatur hubungan antara manusia dengan manusia, hubungan manusia dengan Tuhannya, ${ }^{25}$ dan lain sebagainya.

Pesan-pesan komunikasi terebut, dapat dilihat dalam komunikasi yang dilakukan antara Nabi Ibrahim dengan anaknya dan juga Lukman dengan anaknya yang ada dalam Al-qur,an Surat As-Shafat ayat 102 dan Luqman ayat 13.

"Maka tatkala anak itu sampai (pada umur sanggup) berusaha bersama-sama Ibrahim, Ibrahim berkata: "Hai anakku Sesungguhnya aku melihat dalam mimpi bahwa aku menyembelihmu. Maka fikirkanlah apa pendapatmu!" ia menjawab:

\footnotetext{
22. Miftahul Huda, Interaksi Pendidikan 10 Cara Qur'an Mendidik Anak, (Malang: UIN Malang Press, 2008).hal 1.

23. Abdul Hadi, Konsep Pendidikan Al-Farabi dan Ibnu Sina, Jurnal Ilmiah Sintesa,h. 14.

${ }^{24}$. Effendy, Onong Uchjana. 2009. Komunikasi teori dan praktek. Bandung : PT Remaja Rosdakarya. hal.8

25. M.Natsir,Fiqhud Dakwah (Solo:Cv.Ramadhani,1986).hal.35
} 
"Hai bapakku, kerjakanlah apa yang diperintahkan kepadamu; insya Allah kamu akan mendapatiku Termasuk orang-orang yang sabar". ${ }^{26}$

"Dan (ingatlah) ketika Luqman berkata kepada anaknya, di waktu ia memberi pelajaran kepadanya: "Hai anakku, janganlah kamu mempersekutukan Allah, Sesungguhnya mempersekutukan (Allah) adalah benar-benar kezaliman yang besar". ${ }^{27}$

Ayat ini menggambarkan Nabi Ibrahim sebagai orangtua melakukan sebuah komunikasi antar pribadi yang sangat baik dengan anaknya Nabi Ismail. Liliweri menyatakan bahwa pada hakikatnya komunikasi antar pribadi adalah komunikasi antara seorang komunikator dengan seorang komunikan. Jenis komunikasi tersebut dianggap paling efektif mengubah sikap, pendapat, atau perilaku manusia dikarenakan prosesnya yang dialogis ${ }^{28}$. Sifat dialogis tersebut ditunjukan melalui komunikasi lisan dalam komunikasi yang menampilkan respon yang langsung antara seorang ayah dengan anaknya. Dalam dialog ini sangat jelas bahwa Nabi Ibrahim berkomunikasi pada anaknya Ismail dengan menggunakan bahasa yang sangat baik, sopan dan penuh dengan kasih sayang. Pesan-pesannya berisi penanaman nilai-nilai tauhid dan aqidah yang berisikan dan ajakan ketaatan kepada Allah Swt dengan cara yang sangat lembut yang kemudian dibenarkan oleh Ismail sebagai seorang anak.

Begitu juga dengan apa yang dilakukan Lukman kepada anaknya, dalam komunikasinya, Lukman menggunakan komunikasi dialogis yang hampir senada dengan apa yang dilakukan Nabi Ibrahim. Pesan-pesan yang diberikan kepada anaknya juga merupakan pesan-pesan pendidikan berupa penanaman nilai aqidah untuk mentauhidkan Allah Swt semata dan tidak menyekutukannya yang merupakan nilai-nilai pondasi dasar yang harus diberikan dan diwariskan oleh seorang ayah kepada anaknya. Selain itu, pesan-pesan yang ada dalam ayat pada surat ini mengambarkan proses komunikasi yang secara verbal menanamkan nilai-nilai etika atau akhlak. Melalui komunikasi yang dilakukannya, sebenarnya Nabi Ibrahim dan Lukman sedang melakukan edukasi berupa penanaman nilai-nilai etika atau akhlak yang baik kepada anak-anaknya. Dalam ayat ini dapat dilihat bagaimana Nabi Ibrahim dan Lukman memulai komunikasi edukatifnya kepada anaknya dengan panggilan dan cara yang penuh dengan kasih sayang.

Hal ini sesuai dengan prinsip komunikasi edukatif yang menyatakan bahwa "pendidikan adalah implementasi dari kasih sayang yang secara fitriah dimiliki setiap orang". ${ }^{29}$ Sehingga dari ayat ini dapat dilihat terdapat pesan-pesan tersirat berupa penanaman nilai-nilai etika atau akhlak yang diberikan oleh Nabi Ibrahim dan Lukman selaku komunikator yang tersisip dan tercontohkan dalam cara penyampaian dan pesan komunikasi yag mereka lakukan.

\footnotetext{
${ }^{26}$.Al-qur,an Magfirah. Al-qur,an dan terjemahannya(Jakarta Timur, Magfirah Pustaka:2006) hal.449

27 .Ibid.hal.412

28 . Alo liliweri. Komunikasi Antar-Pribadi, (Bandung: Citra Aditya Bakti,1997).hal.12

29 . Syahidin. Menelusuri Metode Pendidikan dalam Al-Quran. (Bandung: Alfabeta,2009).hal.59
} 


\section{KESIMPULAN}

Dari pembahasan dan hasil kajian tentang isi pesan-pesan yang dalam dalam Al-qur,an, hasil menunjukkan bahwa dalam komunikasi Islam yang konsep komunikasi dasarnya merujuk pada Al-qura,an dan hadits, terdapat banyak sekali ayat-ayat yang menjelaskan secara tersurat dan tersirat aplikasi komunikasi edukatif. Aplikasi ini dapat diihat dari ciri komunikasi edukatif itu sendiri didalam pesannya, yaitu adanya pesan yang berisikan penanaman nilai-nilai edukatif antar komunikator yaitu orangtua, kepada komunikan yaitu anaknya.

Hal ini dapat dilihat dalam Al-qur,an yang di antara dapat dilihat pada beberapa ayat Al-qur,an yang menggambarkan bagaimana berkomunikasinya Nabi Ibrahim sebagai seorang aya dan anaknya Nabi Ismail sebagai seorang anak. Selain itu pesan senada juga dapat dijumpai dalam dialog komunikasi antara Lukman dengan anaknya. Pesan-pesan tersebut berisikan penanaman nilai-nilai pendidikan serta penanaman keyakinan yang fundamental bagi diri manusia khusus untuk jiwa seorang muslim yaitu nilai-nilai tauhid, aqidah dan nilai-nilai moral atau akhlak mulia yang memang seharusnya ditanamkan sejak dini oleh para orangtua kepada anaknya dalam segala hal kehidupan termasuk dalam hal komunikasi.

\section{DAFTAR PUSTAKA}

Al-qur'an Magfirah. 2006. Al-qur,an dan terjemahannya. Jakarta Timur, Magfirah Pustaka.

Cangara, Hafied. 2005. Pengantar Ilmu Komunikasi. Jakarta: Raja Grafindo Persada. Djamarah, Syaiful Bahri. 2005. Guru dan Anak Didik dalam Interaksi Edukatif. Jakarta: PT Rineka Cipta.

Effendi, Mukhlison. 2012. Komunikasi Orang Tua Dengan Anak. Ponorogo: STAIN Ponorogo Press.

Hadi, Abdul. 2010. Konsep Pendidikan Al-Farabi dan Ibnu Sina. Jurnal Ilmiah Sintesa, Vol.9. 2010.

Hasan, IqbaI. 2008. Analisis Data Penelitian Dengan Statistik. Jakarta Bumi Aksara.

Huda, Miftahul. 2008. Interaksi Pendidikan 10 Cara Qur'an Mendidik Anak. Malang: UIN Malang Press.

I. Hovland, Carl. 1953. Social Communication, Dalam Bernard Berlson \& Morris Janowitz (ed), Reader in Public Opinion and Communication. New York: The Free Press of Glencoe.

Kholil, Syukur. 2007. Komunikasi Islam. Bandung: Citapustaka Media,.

Liliweri, Alo. 1997. Komunikasi Antar-Pribadi. Bandung: Citra Aditya Bakti.

Muhammad, Arni. 2014. Komunikasi Organisasi,.Jakarta: PT.Bumi Aksara.

Naim, Ngainun. 2011. Dasar-dasar Komunikasi Pendidikan. Yogyakarta: Ar- Ruzz Media.

Natsi, M. 1986. Fiqhud Dakwah. Solo: Cv.Ramadhani.

Natsir, Muhammad. 1999. Metode Penelitian. Jakarta: Ghalia Indonesia. 
Riswandi. 2009. Ilmu Komunikasi. Jakarta: Graha Ilmu Cetakan Pertama, Suranto A.W. 2010. Komunikasi Sosial Budaya. Yogyakarta: Graha Ilmu. Syahidin. 2009. Menelusuri Metode Pendidikan dalam Al-Quran. Bandung: Alfabeta.

Uchjana Effendy, Onong. 2003. Ilmu, teori dan Filsafat Komunikasi. Bandung: Citra Aditya Bakti. 2009. Komunikasi teori dan praktek. Bandung:PT. Remaja Rosdakarya. 2011. Komunikasi teori dan praktek. Bandung:PT. Remaja Rosdakarya. 